\title{
Can an introduced predator trigger an evolutionary trap in a colonial seabird?
}

\author{
J.M. Igual ${ }^{\mathrm{a}, *}$, M.G. Forero ${ }^{\mathrm{b}}, \mathrm{T}$. Gomez ${ }^{\mathrm{c}}$, D. Oro ${ }^{\mathrm{a}}$ \\ ${ }^{a}$ Instituto Mediterráneo de Estudios Avanzados, IMEDEA (CSIC-UIB), Miquel Marqué s, 21, 07190 Esporles, Mallorca, Spain \\ ${ }^{b}$ Department of Applied Biology, Estación Biológica de Doñana, Avda. María Luisa s/n, Pabellón del Perú, 41013 Sevilla, Spain \\ ${ }^{\mathrm{c}}$ Gestión y Estudios de Espacios Naturales (GENA), S.L, C/Barquillo 30, Madrid, Spain
}

\section{A B S T R A C T}

Keywords:

Ecological trap

Rats

Philopatry Habitat

selection Cory's

shearwater

\begin{abstract}
Animals use environmental cues, social information and behavioural decision-making rules moulded by natural selection to decide where to breed. We assessed whether the presence of an alien nest predator, the Black Rat (Rattus rattus) is used by a colonial seabird, the Cory's shearwater (Calonectris diomedea), as an environmental cue in the selection of breeding sites. We compared potential habitat preference using quality of breeders and nest fidelity as response to nest predation between two sub-colonies with different habitat characteristics, breeding success and predation pressure. Quality of individuals was better in the predated habitat and birds did not perceive the presence of predators signalling differences in predation risk and in turn of breeding success. This failure of perception could be at two levels: in the selection of habitat for first breeding and in the breeding dispersal following a reproductive failure. Preference for the sub-colony with higher predation risk suggests the presence of an evolutionary trap. In fact, the introduction of alien predators probably transformed the behaviour of shearwaters in a maladaptive response due to a mismatch between the new environmental factors and their behavioural and evolutionary algorithms. This can be a common pattern in other species with little behavioural plasticity, evolved in stable environments free of predators.
\end{abstract}

\section{Introduction}

Individuals assess habitat suitability by using the interaction between several cues, namely environmental factors such as nest-site characteristics (Lack, 1968; Birkhead and Furness, 1985; Warham, 1996), predation risk and social mechanisms such as conspecific and heterospecific attraction, mate availability, kin competition and public information (Danchin et al., 1998; Bried and Jouventin, 2002; Serrano et al., 2004; Parejo et al., 2005). In fact, animals often guide their habitat choice decisions on cues that, over evolutionary time, correlate reliably with fitness components as survival and reproductive success (Williams and
Nichols, 1984). Human alterations of the environment can cause a mismatch between formerly reliable cues and individual decisions. It could create evolutionary traps that result in mal-adaptive behaviours with implications for wildlife population dynamics and conservation (Kokko and Sutherland, 2001; Schlaepfer et al., 2002; Kristan, 2003; Battin, 2004; Robertson and Hutto, 2006). A common human alteration of habitat is the introduction of alien species out of their historical ranges, accompanying by their further expansion favoured by anthropogenic activities (Schmidt and Whelan, 1999; Misenhelter and Rotenberry, 2000; Schlaepfer et al., 2005). The invasion of species into native ecosystems is considered one of most important

\footnotetext{
* Corresponding author: Tel.: +34 971611756; fax: +34 971611761.

E-mail address: jm.igual@uib.es(J.M. Igual).
} 
causes of biodiversity loss and ecological alteration (Atckinson, 1985; Vitousek et al., 1997).

Species like seabirds are particularly vulnerable to introduced predators because they lack effective anti-predator behaviours as they normally use habitats free of predators (Moors and Atkinson, 1984; Furness and Monaghan, 1987). For these species, alien black rats (Rattus rattus) have caused in recent centuries a severe impact on their populations and are often involved in the decline and the extinction of their colonies (Atckinson, 1985; Moors et al., 1992; Martin et al., 2000), being breeding success the most affected demographic parameter for medium-size species (Thibault, 1995; Igual et al., 2006).

From an evolutionary point of view, some life-history traits such as philopatry, might limit the reaction of individuals in face of alien predators. Although large differences among populations could exist, in Procellariforms this fixed behaviour (Warham, 1990; Bried and Jouventin, 2002) could constraint the plasticity for habitat selection (Cooch et al., 1992; Spear et al., 1998). Despite this evolutionary trait, populations of Procellariforms are not completely closed: there is still dispersal among and within colonies (Jouventin and Bried, 2001; Martínez-Abraín et al., 2002). One species of Procellariform, the Cory's shearwater Calonectris diomedea, is a good model to assess this hypothesis: at the colony of Chafarinas Islands (SW Mediterranean) chicks are often predated by introduced rats (Igual et al., 2006). A detailed monitoring of breeders allowed us to assess whether nest predation was used as a cue for habitat selection (i.e. adaptive response hypothesis) or not (i.e. trap hypothesis: selection of bad habitat). To address this question we focused on some specific aims: (1) to assess quality of habitat by measuring nest predation probability in two different habitats and (2) to assess the habitat preference of individuals measuring: (a) spatial distribution of individual quality in relation to habitat characteristics and predation pressure, (b) colonization and abandonment rate of breeders in a given habitat, and (c) nest-site fidelity and dispersal of individuals affected by previous breeding experience.

\section{Methods}

\subsection{Study area and population monitoring}

The Chafarinas Islands $\left(35^{\circ} 20^{\circ} \mathrm{N}, 2^{\circ} 25^{\circ} \mathrm{W}\right)$ are $4.5 \mathrm{~km}$ off the Mediterranean coast of Morocco. The archipelago, 53 ha in total, consists of three islands (Congreso, Isabel II and Rey Francisco). The breeding colony of Cory's shearwater (800-2000 pairs) is located principally on Congreso, the largest island of the archipelago (24 ha, 137 m.a.s.l.). The species stays at the breeding colony from the beginning of February to the end of October (pers. obs.). Between 2001 and 2005, all accessible burrows were visited from the end of May to the beginning of June, when most breeders had already laid their eggs. Burrows occupied in preceding years were tagged and checked for the presence of breeding adults. Tagged burrows were re-checked in late September and early October to record breeding success (as percentage of successful nests/ number of nests, where laying was confirmed). Most predation events occurred on young chicks immediately after the brooding stage (Igual et al., 2006), when vegetation productivity (the main food resource for rats) was low (see also Moors et al., 1992; Thibault, 1995).

\subsection{Spatial variation in nest-habitat characteristics}

During 2001, 101 burrows were randomly selected and their associated habitat characteristics were evaluated by variables that measured both physical and also social conditions (Table 1). As some of these variables covary, Categorical Principal Components Analysis (CatPCA in statistical package SPSS) was used for the analysis of the relationship between all variables (categorical ordinals and numerical) and their reduction into a smaller number of components. All considered variables were highly positive or negatively correlated (see dimension component loading in Table 1) and we extracted only one dimension further used as index of burrow type (eigenvalue for dimension one $=5.03$, contribution $=62.85 \%$, Cronbach's $\mathrm{a}=0.92$ ). We obtained an objective index for each burrow. This index achieved high values for burrows of low vegetation cover, high ground complexity (holes, stones), high burrow density and more central position in colony. Considering the burrow index we were able to differentiate two breeding habitats or sub-colonies with different physical and social features, the sub-colony 1 (noted by SC1) showing a lower mean object score than the sub-colony 2 (SC2) (t-Student's test, $\left.\mathrm{t}_{48}=-10.94, \mathrm{P}<0.001\right)$.

During 2001, we also identified causes of breeding failure from predation: on eggs (when shell remains were found inside or near the burrows) or on chicks. Differences in rat predation rates in relation to habitat features were tested by two different procedures. First, we performed a logistic regression to test whether rat predation probability $(0=$ no predation, 1 = predation event) varied with burrow index. Second, we ex-

Table 1 - Results of the categorical principal component analysis for the physical and social features of the burrows

$\begin{array}{lll}\text { Variables } & \text { Variable type }\end{array}$

(1) Density of burrows (radius $5 \mathrm{~m}$ )

(2) Density of burrows (radius $10 \mathrm{~m}$ )

(3) Distance to the nearest burrow (m)

(4) Vegetation cover (radius $5 \mathrm{~m}$ )

(5) Score of ground complexity

(6) Size of stones around the burrow

(7) Number of holes (radius $5 \mathrm{~m}$ )

(8) Position within the colony

$\begin{array}{lr}\text { Numerical } & 0.520 \\ \text { Numerical } & 0.563 \\ \text { Numerical } & -0.695 \\ \text { Ordinal } & -0.851 \\ \text { Ordinal }(1=\text { simple hole; } 2 \text { among stone blocks) } & 1.012 \\ \text { Ordinal }(1 \text { to } 6) & 0.984 \\ \text { Ordinal (less of } 10=1,10-25=2,26-50=3,>50=4) & 1.001 \\ \text { Ordinal }(1=\text { peripheral, } 2=\text { intermediate, } 3=\text { central) } & 0.593\end{array}$

Component loading dimension one 
plored differences in predation rate between sub-colonies with $\mathrm{v}^{2}$-tests.

\subsection{Spatial distribution of individual quality}

During 2001-2005, we took body measurements in a sample of 258 individuals (128 males, 130 females). We measured length of head plus bill, bill, bill depth, tarsus and wing using a digital calliper $\pm 0.1 \mathrm{~mm}$ and weight using a spring balance (precision of $5 \mathrm{~g}$ ) during the same period (20-30 June) for minimising the potential effects of date of capture. As Cory's shearwater is a dimorphic species in size and multivariate measurements of size are preferable to univariate ones (e.g. Forero et al., 2002), we used principal component analysis (PCA), separated for sex, particularly the first axis (PC1), to combine linear body measurements (except body mass) of adults birds. We extracted only one factor, PC1 (used as body size index in further analyses) which accounted for $54.8 \%$ and $54.6 \%$ of the total variance, for males and females, respectively. Body condition index was calculated also by sex as the residuals from the linear regression of body mass on PC1 factor scores $\left(\mathrm{R}=0.64, \mathrm{~F}_{1,127}=87.0, \mathrm{P}<0.001\right.$ for males, $\mathrm{R}=0.66, \mathrm{~F}_{1,129}=101.6, \mathrm{P}<0.001$ for females).

Egg volume has been demonstrated to be a good indicator of female quality in several seabird species (Bolton et al., 1992; Croxall et al., 1992; Mougin, 1998; Michel et al., 2003). During 2001-2005, we measured egg length and width in a sample of 127 nests for which we also recorded female body size. Egg volume was calculated from the equation $\mathrm{V}=$ $0.00051 *$ length $*$ width $^{2}$ (Hoyt, 1979). An additional index of adult quality (egg volume corrected) was calculated as the residuals from the regression between egg volume and body size index of females $\left(\mathrm{R}=0.60, \mathrm{~F}_{1,126}=73.8, \mathrm{P}<0.001\right)$.

Differences in adult quality (both body condition index by sex and corrected egg volume) between sub-colonies were tested using a two-way ANOVA including sub-colony identity and year as factors.

\subsection{Sub-colony dynamics and habitat choice}

To measure the attractiveness of each sub-colony we compared rates of nest abandonment and colonization for the period 2000-2005. We used $v^{2}$ tests to compare the percentage of nests definitively abandoned (for at least the last 2-4 years) as well as the percentage of new nests colonized between both sub-colonies. We also estimated nest preference by measuring the mean number of different breeders that occupied the same nests during the study (in a sample of 60 nests). We applied a t-Student's test to compare nest preference rates at each sub-colony. If individuals were able to select habitat (as it should be the case at least for the first occupation of a burrow), we should expect a higher rate of nest abandon, a lower probability of colonization of new nests and a lower nest preference at the sub-colony with higher predation risk.

\subsection{Response to predation: dispersal behaviour}

For this analysis we considered individuals ringed during 2001-2004 and resighted from 2002 to 2005 (following year) breeding in previously marked burrows. We followed 493 breeding attempts from 240 marked individuals. To investigate factors potentially affecting nest fidelity, we assumed similar survival probability for all individuals in the colony (Boulinier et al., 2002) and compared nest fidelity using a binomial response variable depending on whether the individual bred or not (with sureness) in a marked burrow (in this case, there was not heterogeneity of individual detection since recapture probability at each monitored burrow was 1). Because of such assumption, previous breeding experience was analysed as a categorical explanatory variable with three levels: 0 = breeding failure, 1 = breeding success, 2 = no breeding in the nest (Warham, 1996). We used a Generalized Linear Mixed Model (GLMM, Littlell et al., 1996) to test the influence of subcolony, previous breeding success, sex and their interaction to explain observed nest fidelity by using a binomial error and logit link function. Since in some cases we had multiple return rates (from multiple years) from the same individual, individual identity was treated as a random term in the GLMM using SAS Macro program GLIMMIX (Littlell et al., 1996). The final selected model was built following a forward stepwise procedure which include only the significant effects retained (e.g. Forero et al., 2002).

Since predation rates were different between sub-colonies (see Section 3) an effective behaviour against predation would mean that individuals from the more predated habitat should move to the less predated habitat rather than to the same habitat. Therefore, in addition to the previous analyses we explored the rate of individual nest change within and between each sub-colony by $v^{2}$ tests. In this case, note that here we assumed that the probability of recapture of marked birds was not colony-specific. Estimates of dispersal of marked individuals usually face problems associated with variability in the probability of detecting individuals (Boulinier, 2002): in our case, preliminary analyses of the encounter-history of marked birds that formally compare colony-specific recapture probabilities (Lebreton et al., 1992; White and Burnham, 1999) supported such assumption (data unpublished).

\section{Results \\ 3.1. Spatial variation in nest-habitat characteristics}

We found a negative relationship between nest predation probability (either on egg or on chick) and burrow index (Logistic Regression correctly classified $76 \%$ of values; predation probability $=-1.56-0.99 *$ burrow index, $\mathrm{P}<0.001$, Fig. 1a). Differences in predation rate remained significant (G-test, $\mathrm{G} 1=34.4, \mathrm{P}<0.001$ ) when considering both sub-colonies separately: SC1, with low burrow index (Fig. 1b) showed higher predation pressure $(53 \% ; \mathrm{N}=40)$ than SC2 $(3 \%$; $=61)$. Breeding success was consistently lower at SC1 than at SC2 for all years except in 2005 (Table 2), when no predation event was recorded following the great effort in rat poisoning activity.

\subsection{Spatial distribution of individual quality}

Body condition for males and females and corrected egg volume were also different at both sub-colonies and all 

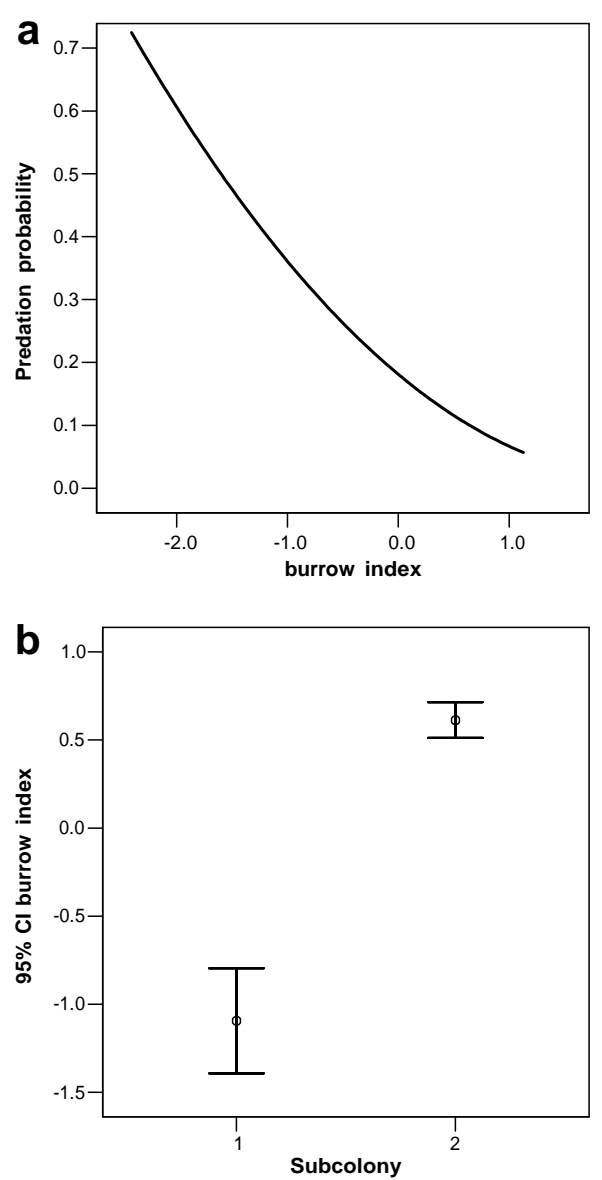

Fig. 1 - (a) Predation probability vs. burrow index: the burrow index increase with ground complexity, number of holes, stone size, burrow density, central position and decrease with vegetation cover around the burrow; (b) burrow index, which defined the two sub-colonies.

parameters also showed variation among study years (Table 3). The lack of significance of the interaction between sub-colony and year in the two previous analyses indicated a consistent relationship between adult quality and habitat characteristics across different years, and consequently in the spatial distribution of individuals in relation to their quality. Individuals of better quality (i.e. better body condition index) and females laying larger eggs bred preferentially at SC1 (Fig. 2), where lower breeding success and higher predation pressure were recorded.

\subsection{Sub-colony dynamics and habitat choice}

We detect at least a similar preference of nests in the subcolony with the highest predation risk. There were no significant differences in the number of different breeders per nest over the years: the mean number of individuals occupying the same nest during 2001-2005 was 3.0 ( $\mathrm{N}=26$ nests) and 2.8 $(\mathrm{N}=34)$ at SC1 and SC2, respectively ( $\mathrm{t}$-test, $\mathrm{t}=0.46, \mathrm{P}=0.68)$. Percentages of nests occupied and later abandoned were similar between sub-colonies $(17 \%$ at SC1 and $12 \%$ at SC2, $\mathrm{v}_{1}^{2} 1 / 40: 84, \mathrm{P}=0.35$ ). However, the frequency of nest coloniza-
Table 2 - Percentage of breeding success (\%BS, expressed as proportion of fledglings relative to eggs laid) and differences between sub-colonies (SC) for the period 1999-2005

\begin{tabular}{llrrrc} 
Year & SC & $\%$ BS & N & $\mathrm{v}_{1}^{2}$ & $P$ \\
\hline 1999 & 1 & 2.4 & 41 & 16.2 & $<0.001$ \\
& 2 & 34.5 & 139 & & \\
2000 & 1 & 57.1 & 46 & 18.3 & $<0.001$ \\
& 2 & 74.6 & 169 & & \\
2001 & 1 & 14.3 & 56 & 20.9 & $<0.001$ \\
& 2 & 64.3 & 154 & & \\
2002 & 1 & 43.2 & 44 & 14.5 & $<0.001$ \\
& 2 & 77.8 & 176 & & \\
2003 & 1 & 45.2 & 42 & 13.7 & $<0.001$ \\
& 2 & 77.7 & 166 & & \\
2004 & 1 & 52.1 & 48 & 12.6 & $<0.001$ \\
& 2 & 75.9 & 174 & & \\
2005 & 1 & 79.6 & 49 & 0.004 & 0.94 \\
& 2 & 79.2 & 192 & & \\
\hline
\end{tabular}

We found that breeding success was consistently lower at SC1 than at SC2 for all years except in 2005 when the highest effort of rat poisoning campaign was recorded.

$\mathrm{N}$ = number of nests monitored.

tion was higher at SC1 $(36 \%, \mathrm{~N}=84)$ than SC2 $(19 \%, \mathrm{~N}=218$; $\left.\mathrm{v}_{1}^{2} 1 / 49: 63, \mathrm{P}=0.002\right)$.

\subsection{Response to predation: dispersal behaviour}

We obtained a model that only included the significant effect of the previous breeding success $\left(\mathrm{F}_{2,257}=24.31 ; \mathrm{P}<0.0001\right)$ controlling by the random effect of the individual identity $(\mathrm{Z}=5.94, \quad \mathrm{P}<0.0001)$. This model accounts for $58.41 \%$ of the original deviance and it indicates that shearwaters tended to change nest site more frequently when they failed reproduction (nest fidelity with previous breeding failure $=60 \%$, $\mathrm{N}=182$, with previous breeding success $=85 \%, \mathrm{~N}=374$, with previous no-breeding year $=80 \%, \mathrm{~N}=25$ ). At some intermediate steps of the modelling, sub-colony identity had a significant effect on site fidelity ( $66 \%$ at SC1, $\mathrm{N}=175,80 \%$ at SC2, $\mathrm{N}=318$ ). Nevertheless sub-colony effect disappeared when breeding success was included in the model and it was only due to the differential probability of breeding success caused by differential predation rates at both sub-colonies.

Nest fidelity was similar independently of the cause of failure: in 2002, the nest fidelity rate of individuals with breeding failure in 2001 for predation was 55\% ( $\mathrm{N}=22)$, with breeding failure for other causes was $49 \%(\mathrm{~N}=39)$ and the fidelity rate of individuals with breeding success was $79 \%(\mathrm{~N}=48)$.

The rate at which individuals changed nest was higher at SC1 (13\%, N = 78 individuals in 26 nest monitored) than at SC2 $\left(2 \%, N=98\right.$ in 34 nest monitored) $\left(v_{1}^{2} 1 / 48: 71, \quad P=0.003\right)$. Therefore, contrary to what we expected under the 'adaptive response hypothesis', all nest changes due to breeding failure took place within the same sub-colony (more in SC1), i.e. we never recorded a case of breeding dispersal between subcolonies. 
Table 3 - Variation in individual quality between sub-colonies and among years

\begin{tabular}{|c|c|c|c|c|c|c|c|c|c|}
\hline & \multicolumn{3}{|c|}{ Body condition males } & \multicolumn{3}{|c|}{ Body condition females } & \multicolumn{3}{|c|}{ Corrected egg volume } \\
\hline & $\mathrm{F}$ & d.f. & $\mathrm{P}$ & $\mathrm{F}$ & d.f. & $\mathrm{P}$ & $\mathrm{F}$ & d.f. & $\mathrm{P}$ \\
\hline Sub-colony & 25.92 & 1.128 & $<0.001$ & 45.99 & 1.130 & $<0.001$ & 12.95 & 1.127 & $<0.001$ \\
\hline Year & 11.91 & 4.128 & $<0.001$ & 4.15 & 4.130 & 0.003 & 2.75 & 4.127 & 0.03 \\
\hline Sub-colony $*$ year & 2.02 & 4.128 & 0.10 & 0.53 & 4.130 & 0.71 & 1.51 & 4.127 & 0.20 \\
\hline
\end{tabular}

\section{Discussion}

Our study met some necessary requirements to support the existence of an evolutionary trap (see Robertson and Hutto, 2006): first, the two studied sub-colonies differed in habitat features; second, individuals showed site preference (at least in the newly occupied burrows); and third, differences in habitat features had fitness consequences (i.e. a significant variation in breeding success). In fact, habitat features and predation probability were associated. Predation pressure decreased with high ground complexity, probably due to the lower detection probability and the increase of search time by predators (Martin and Roper, 1988; Martin, 1993; Martin and Li, 1992; Donázar et al., 1994; Hernandez et al., 1999) and also decreased with low vegetation cover due to a lower rat abundance (Cheylan, 1985). Dilution effect can also explain the lower probability of predation in high density areas
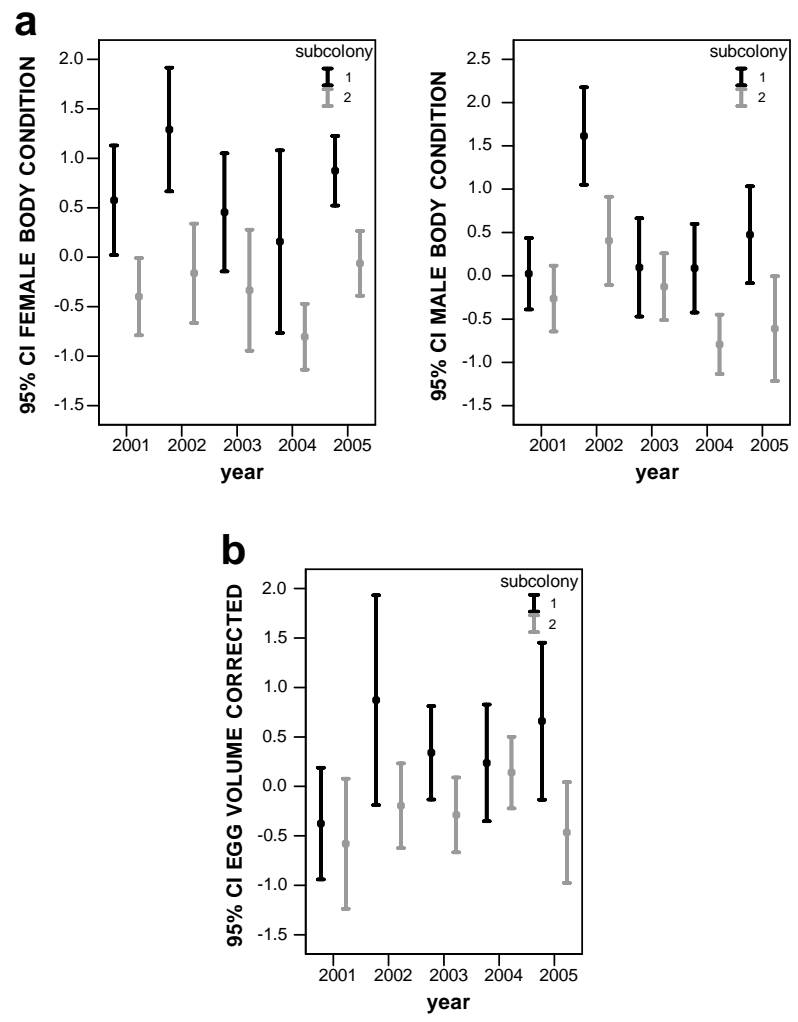

Fig. 2 - Individual quality of adult birds vs. sub-colony for the period 2001-2005: (a) body condition by sex, (b) egg volume corrected by female size. of the colony (Hamilton, 1971; Imber, 1978; Seto and Conant, 1996; Imber et al., 2000).

Strikingly, we also found significant differences between sub-colonies in egg size and individual body condition. Contrarily to what we expected under the theoretical framework of an adaptive habitat selection (Rosenzweig, 1981; Kim and Monaghan, 2005), individuals with higher body condition were found in the habitat where breeding success was lower. This result suggests a primary positive selection of bad quality habitats that trigger a trap at two levels: first, in the "a priori" habitat selection (when birds recruited to a given nest) and secondly, in the "a posteriori" breeding dispersal following reproductive failure since nest changes occurred always within few meters in the same sub-colony (see below and also Thibault, 1994; Mougin et al., 1999). Mechanisms of selection could include assess of fixed cues (active selection) but not exclude natal philopatry or strong reproductive habitat fidelity.

The analysis of nest fidelity showed that dispersal was triggered by reproductive failure and consequently was higher in the sub-colony SC1, where predation was much higher.

Thus, individuals were able to react after breeding failure and to disperse to other nests, as do birds in general (Oro et al., 1999; Hakkarainen et al., 2001; Serrano et al., 2003) and Procellariiforms in particular (Thibault, 1994, 1995; Bried and Jouventin, 1999), but apparently were not able to move to the low-predation habitat (i.e. to escape the trap) for enhancing their fitness. The mechanism triggering the trap was a reduction in habitat suitability without a loss in attractiveness (Robertson and Hutto, 2006). In the absence of predation (year 2005, see also Igual et al., 2006), individuals showed at least the same breeding success at both habitats, despite differences in physical and vegetation features. These facts suggested that environmental cues were honest at signalling fitness consequences (Richner and Heeb, 1996) but that selection, coupled with the presence of alien predators, was maladaptive.

This evolutionary trap was probably the consequence of strategy of habitat selection in Procellariiforms: despite their highly philopatric behaviour and mate fidelity (Mougin, 2000; Bried et al., 2003), there is still space for habitat selection at least for recruits (local and immigrants) and even for residents following breeding failure, in such cases using wrong cues (i.e. ecological traps sensu Battin, 2004). In fact, the colony persists although the birds cohabits with rats at least since the end of the 19th Century (Calderón, 1894), and immigration from other populations could be rescuing the colony from extinction (Thibault, 1995; Martínez-Abraín et al., 2002). 
The evolutionary trap triggered by alien predators would occur for most highly philopatric birds that evolved in very stable environments, which would had not be able at developing mechanisms to recognize this particular cue of bad habitat quality (Doligez et al., 2003; Schlaepfer et al., 2005; Parejo et al., 2006). For such species, predation by alien species is a relatively recent phenomenon in an evolutionary temporal scale, so they probably do not show well-developed mechanisms of rapid reaction through learning. At an individual scale, this behaviour could be maladaptive in terms of individual fitness cost (Spear et al., 1998). All evolutionary traps, including ecological traps, involve the behaviour of individuals and thus we consider that traps are a behavioural rather than a population phenomenon (see also Robertson and Hutto, 2006 opposite to Battin, 2004).

Thus, the relevance of evolutionary traps from a conservation point of view probably depends on the scale of the invasions, i.e. their duration and the proportion of the population affected, and also on the sensitivity to the demographic parameter affected (Lebreton and Clobert, 1991). In long lived seabirds, sensitivity of breeding success is low, being adult survival and dispersal the most important parameters mostly explaining population growth and persistence (Croxall and Rothery, 1991; Cuthbert et al., 2001). However, traps could be critical in situations that increase the sensitivity to fecundity (Lebreton and Clobert, 1991) as is the case in the potential increase of adult mortality in seabirds (including Cory's shearwater) due to fishing gears (Furness, 2003). In conclusion, the evolutionary trap concept proposes a useful framework for managing populations with a mismatch between preferences and habitat qualities. For such species that coexist with invasive predators breeding at small islands, eradication of alien predators is feasible (Donlan et al., 2003; Jouventin et al., 2003; Rodriguez et al., 2006) and probably the best solution also considering both their evolutionary strategies and behavioural ecology.

\section{Acknowledgements}

We are very grateful to I. Afán, G. García, Y. G. Aranda, L. Sanchez, J. Diaz, J.G. Orueta and G. Martínez (GENA, S.L.) for their help during field work. D. Serrano, G. Tavecchia, J.A. Donázar, M. Louzao, M. Genovart, A. Martínez-Abrain, J. Juste and an anonymous referee greatly improved first versions of this manuscript. We also would like to thank J. Zapata (Director of Chafarinas Islands Hunting National Refugee) for his institutional and logistic support. M.G. Forero was supported by a contract of the Program Ramón y Cajal of the Ministerio de Ciencia y Tecnología (MCyT) of Spain. Financial support was provided by the Projects REN2002- 00450/GLO and BOS200301960 from MCyT, and the Organismo Autónomo de Parques Nacionales (OAPN).

\section{R E F E R E N C E S}

Atckinson, I.A.E., 1985. The spread of commensal species of Rattus to oceanic islands and their effects on island avifaunas. In:
Moors, P.J. (Ed.), Conservation of Island Birds. ICBP Publication 3, Cambridge, UK, pp. 35-81.

Battin, J., 2004. When good animals love bad habitats: ecological traps and the conservation of animal populations. Conservation Biology 18, 1482-1491.

Birkhead, T.R., Furness, R.W., 1985. The regulation of seabird populations. In: Sibly, R.M., Smith, R.H. (Eds.), Behavioural Ecology. Blackwell Scientific Publications, Oxford, pp. 147-168.

Bolton, M., Houston, D., Monaghan, P., 1992. Nutritional constraints on egg formation in the lesser black-backed gull: an experimental study. Journal of Animal Ecology 61, 521-532.

Boulinier, T., Yoccoz, N.G., McCoy, K.D., Erikstad, K.E., Tveraa, T., 2002. Testing the effect of conspecific reproductive success on dispersal and recruitment decisions in a colonial bird: design issues. Journal of Applied Statistics 29, 509-520.

Bried, J., Jouventin, P., 1999. Influence of breeding success on fidelity in long-lived birds: an experimental study. Journal of Avian Biology 30, 392-398.

Bried, J., Jouventin, P., 2002. Site and mate choice in seabirds: an evolutionary approach. In: Schreiber, E.A., Burger, J. (Eds.), Biology of Marine Birds. CRC Marine Biology Series. CRC Press, pp. 263-305.

Bried, J., Pontier, D., Jouventin, P., 2003. Mate fidelity in monogamous birds: a re-examination of the Procellariiformes. Animal Behaviour 65, 235-246.

Calderón, S., 1894. Las Chafarinas. Anales de la Sociedad Española de Historia Natural 23, 903-917.

Cheylan, G., 1985. La pré dation exercée par le rat noir Rattus rattus sur les oiseaux de mer nicheurs dans les îles Méditerranéennes. Annales du CROP 2, 27-29.

Cooch, E.G., Jefferies, R.L., Rockwell, R.F., Cooke, F., 1992. Environmental change and the cost of philopatry: an example in the lesser snow goose. Oecologia 93, 128-138.

Croxall, J.P., Rothery, P., 1991. Population regulation of seabirds: implications of their demography for conservation. In: Perrins, C.M., Lebreton, J.D., Hirons, J.M. (Eds.), Bird Population Studies: Relevance to Conservation and Management. Oxford University Press, pp. 775-796.

Croxall, J.P., Rothery, P., Crisp, A., 1992. The effect of maternal age and experience on egg size and hatching success in Wandering Albatrosses Diomedea exulans. Ibis 134, 219-228.

Cuthbert, R., Flecher, D., Davis, L.S., 2001. A sensitivity analysis of Hutton's shearwater: prioritizing conservation research and management. Biological Conservation 100, 163-172.

Danchin, E., Boulinier, T., Massot, M., 1998. Conspecific reproductive success and breeding habitat selection: implications for the study of coloniality. Ecology 79, 2415-2428.

Donázar, J.A., Ceballos, O., Traviani, A., Rodriguez, A., Funes, M., Hiraldo, F., 1994. Breeding performance in relation to nest-site substratum in a Buff-necked Ibis (Theristicus caudatus) population in Patagonia. Condor 96, 994-1002.

Doligez, B., Cadet, C., Danchin, E., Boulinier, T., 2003. When to use public information for various breeding selection for breeding habitat selection? The role of environmental predictability and density dependence. Animal Behaviour 66, 973-988.

Donlan, C.J., Tershy, B.R., Campbell, K., Cruz, F., 2003. Research for requiems: the need for more collaborative action in eradication of invasive species. Conservation Biology 17, 1850-1851.

Forero, M.G., Tella, J.L., Hobson, K.A., Bortolotti, G.R., Bertellotti, M., Blanco, G., 2002. Conspecific food competition explains variability in colony size: a test in Magellanic penguins. Ecology 83, 3466-3475.

Furness, R.W., 2003. Impacts of fisheries on seabird communities. Scientia Marina 67, 33-45.

Furness, R.W., Monaghan, P., 1987. Seabird Ecology. Blackie and Son Ltd., London. 
Hakkarainen, H., Ilmonen, P., Koivunen, V., Korpimäki, E., 2001. Experimental increase of predation risk induces breeding dispersal of Telgmam's owl. Oecologia 126, 355-359.

Hamilton, W.J., 1971. Geometry for the selfish herd. Journal of Theoretical Biology31, 295-311.

Hernandez, M., Martin, A., Nogales, M., 1999. Breeding success and predation on artificial nests of the endemic pigeons Bolle's Laurel Pigeon, Columba bollii, and White-tailed Pigeon, Columba junoniae in the Laurel forest of Tenerife (Canary Islands). Ibis 141, 52-59.

Hoyt, D.F., 1979. Practical methods of estimating volume and fresh weight of bird eggs. Auk 96, 73-77.

Igual, J.M., Forero, M.G., Gomez, T., Orueta, J.G., Oro, D., 2006. Rat control and breeding performance in Cory's Shearwaters: effects of poisoning effort and habitat features. Animal Conservation 9, 59-65.

Imber, M.J., 1978. The effects of rats on breeding success of petrels. In: Dingwall, P.R., Atkinson, I.A.E., Hay, C. (Eds.), The Ecology and Control of Rodents in New Zealand Nature Reserves. Department of Land and Survey Information Series, New Zealand.

Imber, M., Harrison, M., Harrison, J., 2000. Interactions between petrels, rats and rabbits on Whale Island, an effects of rat and rabbit eradication. New Zealand Journal of Ecology 24, 153-160.

Jouventin, P., Bried, J., 2001. The effect of mate choice on speciation in snow petrels. Animal Behaviour 62, 123-132.

Jouventin, P., Bried, J., Micol, T., 2003. Insular bird populations can be saved from rats: a long-term experimental study of whitechinned petrels Procellaria aequinoctialis on Ile de la Possession (Crozet Archipelago). Polar Biology 26, 371-378.

Kim, S.-Y., Monaghan, P., 2005. Interacting effects of nest shelter and breeder quality on behaviour and breeding performance of herring gulls. Animal Behaviour 69, 301-306.

Kokko, H., Sutherland, W.J., 2001. Ecologicaltraps in changing environments: ecological and evolutionary consequences of a behaviourally mediated Allee effect. Evolutionary Ecology Research 3, 537-551.

Kristan, W.B., 2003. The role of habitat selection behaviour in population dynamics: source-sink systems and ecological traps. Oikos 103, 457-468.

Lack, D., 1968. Ecological Adaptations for Breeding in Birds. Methuen, London.

Lebreton, J.D., Clobert, J., 1991. Bird population dynamics, management, and conservation: the role of mathematical modelling. In: Perrins, C.M., Lebreton, J.-D., Hirons, G.J.M. (Eds.), Bird Population Studies. Oxford University Press, Oxford, pp. 105-125.

Lebreton, J.D., Burnham, K.P., Clobert, J., Anderson, D.R., 1992. Modelling survival and testing biological hypotheses using marked animals: a unified approach with case studies. Ecological Monographs 62, 67-118.

Littlell, R.C., Milliken, G.A., Stroup, W.W., Wolfinger, R.D., 1996. SAS System for Mixed Models. SAS Institute, Cary.

Martin, J.L., Thibault, J.C., Bretagnolle, V., 2000. Black rats, island characteristics and colonial nesting birds in the Mediterranean: consequences of an ancient introduction. Conservation Biology 14, 1452-1466.

Martin, T.E., 1993. Nest predation among vegetation layers and habitat types: revising the dogmas. American Naturalist 141 , 897-913.

Martin, T.E., Roper, J.J., 1988. Nest predation and nest site selection in a western population of the Hermit Thrush. Condor 90, 51-57.

Martin, T.E., Li, P., 1992. Life history traits of open-versus cavitynesting birds. Ecology 73, 579-592.

Martínez-Abraín, A., Sanchez, A., Oro, D., 2002. Atlantic Cory’s Shearwaters (Calonectris diomedea borealis) breeding in a colony of Mediterranean Cory's Shearwater (C. d. diomedea). Waterbirds 25, 221-224.

Michel, P., Ollason, J.C., Grosbois, V., Thompson, P.M., 2003. The influence of body size, breeding experience and environmental variability on egg size in the northern fulmar (Fulmarus glacialis). Journal of Zoology 261, 427-432.

Misenhelter, M.D., Rotenberry, J.T., 2000. Choices and consequences of habitat occupancy and nest site selection in Sage Sparrows. Ecology 81, 2892-2901.

Moors, P.J., Atkinson, I.A E., 1984. Predation on Seabirds by Introduced Animals, and Factors Affecting its Severity. ICBP Technical Publication 2. pp. 667-690.

Moors, P.J., Atckinson, I.A.E., Sherley, G.H., 1992. Reducing the rat threat to island birds. Bird Conservation International 2, 93-114.

Mougin, J.L., 1998. Factors affecting egg dimensions and breeding success in the Cory’s Shearwater (Calonectris diomedea) of Salvagem Grande. Journal of Ornithology 139, 179-184.

Mougin, J.L., Granadeiro, J.P., Jouanin, C., Roux, F., 1999. Philopatry and faithfulness to nest site in Cory's shearwaters Calonectris diomedea at Salvagem Grande. Ostrich 70, 229-232.

Mougin, J.L., 2000. Pairing in the Cory's shearwater (Calonectris diomedea) of Salvagem grande. Journal of Ornithology 141, 319-326.

Oro, D., Pradel, R., Lebreton, J.D., 1999. Food availability and nest predation influence life history traits in Audouin's gull, Larus audouinii. Oecologia 118, 438-445.

Parejo, D., Danchin, E., Aviles, J.M., 2005. The heterospecific habitat copying hypothesis: can competitors indicate habitat quality? Behavioral Ecology 16, 96-105.

Parejo, D., Oro, D., Danchin, E., 2006. Is “Habitat copying” used by a species adapted to variable environments? The importance of the spatial scale. Ibis 148, 146-154.

Richner, H., Heeb, P., 1996. Communal life: honest signalling and the recruitment centre hypothesis. Behavioral Ecology 7, 115-119.

Robertson, B.A., Hutto, R.L., 2006. A framework for understanding ecological traps and an evaluation of existing evidence. Ecology 87, 1075-1085.

Rodriguez, C., Torres, R., Drummond, H., 2006. Eradicating introduced mammals from a forested tropical island. Biological Conservation 130, 98-105.

Rosenzweig, M.L., 1981. A theory of habitat selection. Ecology 62, 327-335.

Schlaepfer, M.A., Runge, M.C., Sherman, P.W., 2002. Ecological and evolutionary traps. Trends in Ecology and Evolution 17, 474-480.

Schlaepfer, M.A., Sherman, P.W., Blossey, B., Runge, M.C., 2005. Introduced species as evolutionary traps. Ecology Letters 8, 241-246.

Schmidt, K.A., Whelan, C.J., 1999. Effects of exotic Lonicera and Rhamnus on Songbird nest predation. Conservation Biology 13, 1502-1506.

Serrano, D., Tella, J.L., Donázar, J.A., Pomarol, M., 2003. Social and individual features affecting natal dispersal in the colonial lesser kestrel. Ecology 84, 3044-3054.

Serrano, D., Forero, M.G., Donazar, J.A., Tella, J.L., 2004. Dispersal and social attraction affect colony selection and dynamics of lesser kestrels. Ecology 85, 3428-3447.

Seto, N.W.H., Conant, S., 1996. The effects of rat (Rattus rattus) predation on the reproductive success of the Bonin Petrel (Pterodroma hypoleuca) on Midway Atoll. Colonial Waterbirds 19, 171-185.

Spear, L.R., Pyle, P., Nur, N., 1998. Natal dispersal in the Western Gull: proximal factors and fitness consequences. Journal of Animal Ecology 67, 165-179. 
Thibault, J.C., 1994. Nest site tenacity and mate fidelity in relation to breeding success in Cory's shearwater Calonectris diomedea. Bird Study 41, 25-28.

Thibault, J.C., 1995. Effect of predation by the black rat Rattus rattus on the breeding success of Cory's Shearwater Calonectris diomedea in Corsica. Marine Ornithology 23, 1-10.

Vitousek, P.M., Mooney, H.A., Lubchenco, J., Melillo, J.M., 1997. Human domination of Earth's ecosystems. Science 277, 494-499.
Warham, J., 1990. The Petrels. Their Ecology and Breeding Systems. Academic Press, London.

Warham, J., 1996. The Behaviour, Population Biology and Physiology of the Petrels. Academic Press, London.

Williams, B.K., Nichols, J.D., 1984. Optimal timing in biological processes. American Naturalist 123, 1-19.

White, G.C., Burnham, K.P., 1999. Program MARK: survival estimation from populations of marked animals. Bird Study 46, 120-129. 